\title{
ISOLASI Actinomycetes ENDOFIT DARI TANAMAN AKAR WANGI (Vetiveria zizanioides) DAN UJI AKTIVITAS SENYAWA ANTIBAKTERI TERHADAP Staphylococcus aureus DAN Escherichia coli
}

\author{
Elsie, Nofripa Herlina, Ruli Tias Putri \\ Department of Biology, Faculty of Mathematic and Natural Sciences, \\ Universitas Muhammadiyah Riau \\ elsie@umri.ac.id

\section{ABSTRACT}

Actinomycetes endophytes are bacteria that live in plant tissues and are known as secondary metabolites that have activity as an antibacterial. This study was conducted to isolate Actinomycetes endophytes from vetiver plant tissue (Vetiveria zizanioides) and test for the activity of antibacterial compounds against Staphylococcus aureus and Escherichia coli by using diffusion method. Actinomycetes endophytes successfully isolated were isolates of RTP-1, RTP-2 and RTP-3. The results of antibacterial compound activity test showed that the three Actinomycetes endophytic isolates were able to inhibit the growth of $S$. aureus and E. coli bacteria. The best inhibitory ability against E. coli bacteria with a drag zone diameter of $20 \mathrm{~mm}$ while the largest inhibitory zone diameter against S. aureus bacteria was $9 \mathrm{~mm}$.

Keywords : Actinomycetes endophytes, Vetiveria zizanioides, antibacterials

\section{PENDAHULUAN}

Penyakit akibat infeksi merupakan salah satu masalah dalam bidang kesehatan yang terus berkembang. Beberapa mikroorganisme penyebab infeksi diantaranya virus, jamur, protozoa dan bakteri. Salah satu cara meminimalisir penyakit infeksi yaitu dengan penggunaan antibiotik. Namun banyak mikroba yang mengalami resistensi terhadap antibiotik. Banyaknya kejadian resistensi mendorong dilakukannya eksplorasi antibiotik baru sebagai upaya mengatasi masalah resistensi ini. Sumber utama penghasil antibiotik berasal dari fungi (Worang, 2003), bakteri (Suarsana et al., 2001) dan Actinomycetes (Oskay et al., 2004).

Actinomycetes merupakan bakteri Gram positif berbentuk batang yang umumnya hidup di tanah (Waluyo, 2009), namun ada juga ditemukan pada jaringan tanaman (batang, daun, akar) sehat dan menghasilkan sumber senyawa bioaktif yang memberi lebih banyak keuntungan seperti produksi antibiotik, antikanker, antibakteri, dan fitohormon yang disebut Actinomycetes endofit (Bailey et al., 2006;.Clegg \& Murray, 2002).

Beberapa penelitian telah dilakukan sebelumnya untuk mengisolasi Actinomycetesendofit dari jaringan tanaman.Cao et al. (2004) telah menemukan isolat Streptomyces dari akar tanaman tomat diketahui telah memberi manfaat sebagai pengendali penyakit infeksi dengan kemampuannya dalam menghasilkan senyawa antibakteri. Penelitian yang dilakukan Castillo et al. (2002) menunjukkan bahwa Streptomyces NRRL 30562 dari tanaman Kennedia nigriscans menghasilkan munumbisin (antibiotik) dan munumbisin D (antimalaria), sedangkan penelitian Strobel et al. (2004) menyebutkan bahwa Serratia marcescens dari tanaman Rhyncholacis penicillata menghasilkan oosydin A sebagai antifungi dan penelitian Beck et al. (2003) 
telah menemukan senyawa fusarisidin A-D sebagai antifungi dari tanaman Triticum aestivum yang mewakili family poaceae. Tanaman yang termasuk family poaceae lainnya yaitu akar wangi

Akar wangi (Vetiveria zizanioides) adalah tanaman tropis sejenis rumput-rumputan berukuran besar yang memiliki banyak keistimewaan. Tanaman tersebut banyak dimanfaatkan sebagai penghasil minyak atsiri yang menghasilkan banyak kandungan bioaktif seperti antiinflamasi, antiseptik dan obat luka (Chomchalow, 2000). Penelitian yang dilakukan Ratha et al. (2012), menunjukkan bahwa ekstrak tanaman Vetiveria zizanioides diketahui mempunyai aktivitas antibakteri terhadap Escherichia coli, Klebseilla pnemoniae, Salmonella typhii, Staphylococcus aureus, dan Vibrio cholera. Berdasarkan hal tersebut, diperkirakan, pada tanaman Akar Wangi (Vetiveria zizanioides) terdapat mikroba aktif seperti Actinomycetes endofit yang memproduksi zat antibakteri. Untuk mengukur seberapa besar potensi senyawa antibakteri dapat memberikan efek bagi bakteri patogen, maka dilakukan uji aktivitas antibakteri terhadap bakteri taget yaitu $S$. aureus dan E. coli.

\section{Batasan Masalah}

Pada penelitian ini penulis hanya membatasi pada isolasi Actinomycetes endofit dari akar dan daun tanaman Akar Wangi (Vetiveria zizanioides) dan melakukan uji aktivitas antibakteri terhadap bakteri target yaitu Staphylococcus aureus dan Escherichia coli.

\section{Rumusan Masalah}

Eksplorasi Actinomycetes endofit sebagai penghasil antibiotik baru dan kemampuannya dalam menghasilkan zat antibakteri mulai dikembangkan untuk menjawab kebutuhan obat di dunia kesehatan, sehingga mendorong penulis melakukan isolasi Actinomycetes endofit dari jaringan tanaman Akar Wangi (Vetiveria zizanioides) yang memiliki potensi dalam menghasilkan senyawa antibakteri.

\section{Tujuan Penelitian}

Tujuan penelitian ini adalah mengisolasi Actinomycetes endofit dari akar dan daun tanaman Akar Wangi (Vetiveria zizanioides) dan uji aktivitas antibakteri terhadap Staphylococcus aureus dan Escherichia coli.

\section{Manfaat Penelitian}

Penelitian ini diharapkan dapat memberikan informasi mengenai isolat Actinomycetes endofit yang diisolasi dari akar dan daun tanaman Akar Wangi (Vetiveria zizanioides) yang potensial dalam menghasilkan senyawa antibakteri terhadap Staphylococcus aureus dan Escherichia coli.

\section{METODOLOGI PENELITIAN}

Penelitian ini dilaksanakan pada bulan April hingga Juni 2017. Sampel tanaman akar wangi diambil di Kecamatan Rumbai Pesisir dan analisis sampel dilakukan di Laboratorium Mikrobiologi Fakultas MIPA dan Kesehatan, Universitas Muhammadiyah Riau, Pekanbaru.

\section{Alat Dan Bahan}

Alat yang digunakan dalam penelitian ini adalah plastik ziplock, penggaris, Laminar Air Flow (LAF), oven (Memmert), inkubator (Memmert), autoklaf (All American), timbangan analitik (Radwag), kompor listrik (Maspion), beaker glass (Pyrex), cawan petri (Pyrex), pipet volume $1 \mathrm{ml}$, erlenmeyer, bunsen, cotton swab, tabung reaksi, spatula, pinset, ose dan pisau.

Bahan yang digunakan pada penelitian ini adalah sampel akar dan daun V. zizanioides, media Starch Casein Agar, Starch Casein Broth, media Nutrient Agar, Nutrient Broth, antifungi (Nistatin), kertas saring, aquades, alkohol $70 \%$, natrium hipoklorit $(\mathrm{NaOCl}) 5,25$ $\%$, spiritus, bakteri uji S. aureus dan E. coli (diperoleh dari Laboratorium Mikrobiologi 
Fakultas MIPA, Universitas Muhammadiyah Riau)

\section{Isolasi Actinomycetes Endofit}

Isolasi Actinomycetes endofit dari akar dan daun $V$. zizanioides dilakukan berdasarkan metode Coombs \& Franco (2003), dimulai dengan mengoleksi tanaman dari lapangan selanjutnya dibersihkan dari kotoran dengan cara mencucinya pada air mengalir. Akar dan daun tanaman dipotong secara aseptik dengan pisau menjadi potongan-potongan berukuran \pm $1 \mathrm{~cm}$. Potongan-potongan tersebut disterilisasi dengan cara direndam ke dalam larutan alkohol $70 \quad \%$ selama 1 menit, natrium hipoklorit $(\mathrm{NaOCl}) 5,25 \%$ selama 5 menit, kemudian direndam kembali ke dalam larutan alkohol $70 \%$ selama 1 menit, potonganpotongan akar dan daun tersebut dibilas tiga kali dengan aquades steril. Kemudian, potongan akar atau daun dikeringkan dengan tisu steril dan dibiarkan selama 2-3 jam.

Sampel akar dan daun $V$. zizanioides diinokulasi ke dalam cawan petri. Setiap cawan petri yang sudah berisi media SCA berisi 2 potong akar atau daun. Sebagai kontrol, aquades bilasan terakhir diambil \pm 1 $\mathrm{ml}$ dan dituang ke dalam media SCA. Sampel tanaman yang sudah diinokulasi, selanjutnya diinkubasi pada suhu $28^{\circ} \mathrm{C}$ selama 2 minggu untuk melihat pertumbuhan Actinomycetes endofit.

\section{Pemurnian Isolat Actinomycetes Endofit}

Pemurnian Actinomycetes endofit dilakukan pada setiap koloni yang dianggap berbeda berdasarkan morfologi makroskopis yang dapat dilihat dari penampakan warna meliputi hifa aerial, hifa substrat dan ada tidaknya pigmen yang terdifusi ke medium (pigmen terlarut) dan memproduksi spora seperti serbuk (Susilowati, 2007). Actinomycetes endofit tersebut diambil menggunakan ose dan dipindahkan ke media SCA yang baru dengan metode streak plate untuk mendapatkan isolat murni. Isolat diinkubasi pada suhu $28{ }^{\circ} \mathrm{C}$ selama 2 minggu (Sembiring et al., 2000).

\section{Produksi Senyawa Antibakteri}

Isolat murni Actinomycetes endofit yang telah diperoleh diambil menggunakan ose steril kemudian diinokulasikan ke dalam tabung reaksi berisi $9 \mathrm{ml}$ media SCB, diinkubasi pada suhu $28{ }^{\circ} \mathrm{C}$ selama 7 hari. Pertumbuhan bakteri ditandai dengan terbentuknya granul-granul, serta terjadi perubahan warna pada media menjadi sedikit keruh (Herlina et al., 2010).

\section{Membuat Suspensi Bakteri Target}

Satu ose biakan bakteri yang telah diremajakan di media NA disuspensikan ke dalam tabung reaksi berisi $5 \mathrm{ml}$ media NB dan diinkubasi selama 24 jam pada suhu $37{ }^{\circ} \mathrm{C}$. Suspensi bakteri tersebut diencerkan menggunakan aquades steril sampai kekeruhannya setara dengan larutan standard Mc.Farland I (biakan cair yang kekeruhannya setara dengan 0,5 Mc.Farland I mempunyai populasi $\left.1 \times 10^{7} \quad \mathrm{CFU} / \mathrm{ml}-1 \times 10^{8} \quad \mathrm{CFU} / \mathrm{ml}\right)$ (Sutton, 2011).

\section{Uji Potensi Isolat Sebagai Penghasil Antibakteri}

Uji aktivitas antibakteri dilakukan dengan menggunakan metode difusi (Susilowati et al., 2007). Media NA diusap sampai merata dengan suspensi bakteri target yang kekeruhannya setara dengan 0,5 Mc.Farland I menggunakan cotton swab, kemudian kertas saring berdiameter $6 \mathrm{~mm}$ steril dicelupkan selama 5 detik ke dalam suspensi isolat Actinomycetes endofit menggunakan pinset steril. Potongan kertas saring tersebut diletakkan di atas media NA yang telah diusap dengan bakteri uji. Selanjutnya seluruh cawan diinkubasi pada suhu $28{ }^{\circ} \mathrm{C}$ selama 24 jam. Setelah itu dilakukan pengamatan zona hambat di sekitar kertas saring yang menunjukkan tidak adanya pertumbuhan bakteri. Diameter 
daerah hambatan dihitung dan ditentukan tingkat hambatannya sesuai dengan pengkategorian Ambarwati (2007), yaitu zona bening dengan diameter $<5 \mathrm{~mm}$ dikategorikan lemah, 5-9 mm dikategorikan sedang, 10-20 mm dikategorikan kuat, sedangkan zona bening dengan diameter $>20 \mathrm{~mm}$ dikategorikan sangat kuat.

\section{Analisis Data}

Data yang diperoleh dari hasil isolasi Actinomycetes endofit dari tanaman Akar Wangi ( $V$. zizanioides) disajikan dalam bentuk tabel dan gambar, serta dijelaskan secara deskriptif berdasarkan ukuran zona hambat.

\section{HASIL DAN PEMBAHASAN}

Hasil isolasi, Actinomycetes endofit dari tanaman akar wangi (V. zizanioides) disajikan pada (Tabel 1).

Tabel 1 Hasil isolasi dan karakterisasi morfologi Actinomycetes endofit

\begin{tabular}{ccccccc}
\hline \multirow{2}{*}{ No } & Isolat & $\begin{array}{c}\text { Organ } \\
\text { tanaman }\end{array}$ & Hifa aerial & $\begin{array}{c}\text { Hifa } \\
\text { substrat }\end{array}$ & Pigmen terlarut & spora \\
\cline { 5 - 7 } & RTP-1 & Daun & Putih & Kuning & Kekuningan & Serbuk \\
\hline 1 & RTP-2 & Daun & $\begin{array}{c}\text { Putih merah } \\
\text { muda }\end{array}$ & Merah & Tidak ada & Serbuk \\
\hline 3 & RTP-3 & Akar & $\begin{array}{c}\text { Putih } \\
\text { kecoklatan }\end{array}$ & Coklat & Tidak ada & Serbuk \\
\hline
\end{tabular}

Tabel 1 menunjukkan bahwa hasil isolasi Actinomycetes endofit dari dalam jaringan tanaman akar wangi (V. zizanioides) diperoleh sebanyak 3 isolat, dua isolat berasal dari jaringan daun dan satu isolat dari jaringan akar. Ketiga isolat tersebut adalah isolat RTP1, RTP-2 dan RTP-3. Karakteristik morfologi makroskopis yang diamati meliputi warna hifa aerial, warna hifa substrat, warna pigmen terlarut dan memproduksi spora seperti serbuk.

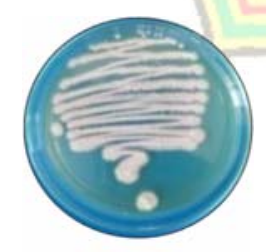

(a1)

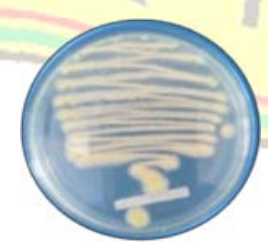

(a2)
Hifa aerial merupakan hifa yang menonjol atau terbentuk dari permukaan substrat yang berfungsi sebagai alat perkembangbiakan. Hifa substrat adalah hifa yang terbentuk di bagian dasar/bawah dari kultur Actinomycetes berfungsi sebagai alat untuk menyerap nutrisi sedangkan pigmen terlarut adalah warna yang disekresikan oleh kultur ke dalam media tumbuh (Gambar 1).

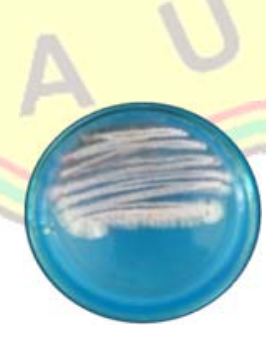

(b1)

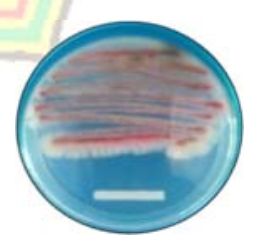

(b2) 


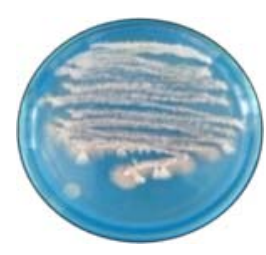

(c1)

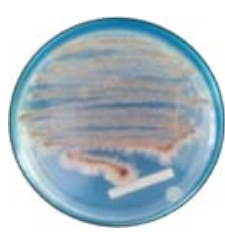

(c2)

Gambar 1 Keragaman morfologi koloni Actinomycetes endofit pada media SCA (a1) warna hifa aerialisolat RTP-1, (a2) warna hifa substrat isolat RTP-1; (b1) warna hifa aerial isolat RTP-2,

(b2) warna hifa substrat isolat RTP-2; (c1) warna hifa aerial isolat RTP-3, (c2) warna hifa substrat isolat RTP-3

Karakteristik morfologi ketiga isolat RTP-

1, RTP-2 dan RTP-3 masing-masing menunjukkan warna hifa aerial putih, putih merah muda, putih kecoklatan dan warna hifa substrat kuning, merah, coklat dan memproduksi spora seperti serbuk sedangkan yang memiliki kemampuan dalam menghasilkan warna pigmen terlarut pada medium yaitu isolat RTP-1 dimana warna awal medium bening tidak berwarna berubah menjadi kekuningan. Perubahan warna yang terjadi pada medium ini disebabkan adanya senyawa metabolit sekunder yang dihasilkan Actinomycetes endofit. Miyadoh dan Otoguro (2004) mengatakan bahwa spora Actinomycetes akan berkembang menjadi miselium dan mampu mengubah warna medium (terdifusi) apabila nutrisi, kelembaban udara, suhu, serta kondisi lainnya memenuhi untuk kehidupannya, sehingga lebih dominan menghasilkan metabolit sekunder dan pertumbuhan sel. Berdasarkan penelitian Amal et al. (2011), menunjukkan bahwa pigmen tedifusi Actinomycetes biasanya terdiri dari beragam warna seperti gradasi biru, ungu, merah, kuning, coklat, dan hitam.

Hasil pengamatan menunjukkan adanya perbedaan warna pigmen yang dihasilkan diantara ketiga isolat, hal ini terjadi karena masing-masing isolat memiliki peran biologis yang berbeda seperti antibiotik, antitumor, antifungi, antiinflamasi dan vitamin. Lo et al. (2002) menyatakan bahwa keanekaragaman warna Actinomycetes disebabkan adanya pigmen rantai spora yang dimiliki Actinomycetes, hifa akan berubah menjadi warna tertentu apabila terjadi pembentukan spora, sehingga diperoleh warna yang berbeda. Pigmen yang dihasilkan tersebut memiliki kemampuan biologis seperti antibiotik, antitumor, vitamin dan lain-lain.

Produksi Actinomycetes endofit dari tanaman akar wangi dilakukan menggunakan media SCB selama 7 hari bertujuan untuk menghasilkan metabolit sekunder yang ditandai dengan terbentuknya granul dan perubahan media menjadi sedikit keruh (Lampiran 2). Menurut Khamma et al. (2008) waktu fermentasi pada media cair paling baik untuk pertumbuhan Actinomycetes yaitu 7-14 hari, sehingga metabolit sekunder yang dihasilkan lebih optimum.

\section{Uji Aktivitas Senyawa Antibakteri Terhadap S. aureus danE. coli}

Hasil uji aktivitas senyawa antibakteri serta pengukuran zona bening isolat Actinomycetes endofit terhadap bakteri target (S. aureus dan E. coli) disajikan pada Tabel 2. 
Tabel 2 Hasil uji aktivitas antibakteri terhadap S. aureus dan E. Coli

\begin{tabular}{cccccc}
\hline \multirow{2}{*}{ No } & \multirow{5}{c}{ Zona Hambat Terhadap Bakteri Uji (mm) } \\
& & \multicolumn{3}{c}{} & \\
\cline { 3 - 5 } & & S. aureus & Kategori & E. coli & Kategori \\
\hline 1 & RTP-1 & $1 \mathrm{~mm}$ & Lemah & $20 \mathrm{~mm}$ & Kuat \\
\hline 2 & RTP-2 & $9 \mathrm{~mm}$ & Sedang & $4 \mathrm{~mm}$ & Lemah \\
\hline 3 & RTP-3 & $7 \mathrm{~mm}$ & Sedang & $9 \mathrm{~mm}$ & Sedang \\
\hline
\end{tabular}

Uji antagonis antibakteri ketiga isolat RTP-1, RTP-2 dan RTP-3 masing-masing terhadap $S$. aureus menghasilkan zona hambat sebesar $1 \mathrm{~mm}, 9 \mathrm{~mm}$ dan $7 \mathrm{~mm}$. sedangkan terhadap E. coli menghasilkan zona hambat sebesar $20 \mathrm{~mm}, 4 \mathrm{~mm}$, dan 9 mm dengan pengkategorian kuat, sedang dan lemah. Diameter zona hambat terbesar terhadap S. aureus dihasilkan oleh isolat RTP-2 yaitu $9 \mathrm{~mm}$ sedangkan diameter zona hambat terbesar terhadap E. coli dihasilkan oleh isolat RTP-1 yaitu $20 \mathrm{~mm}$ (Gambar 2)

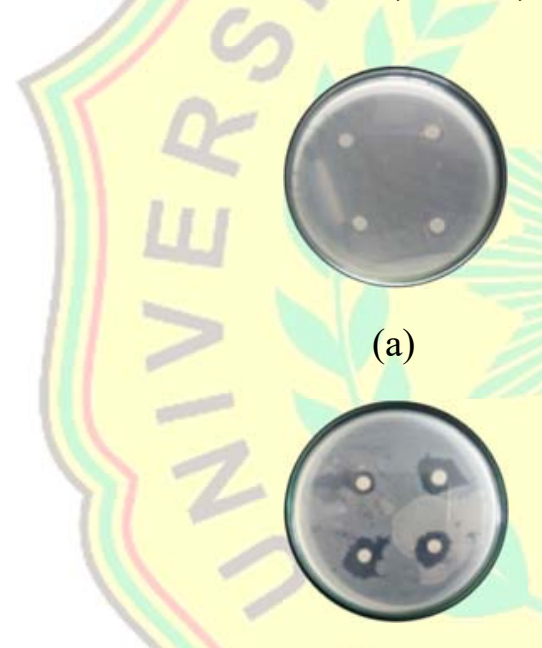

(d)

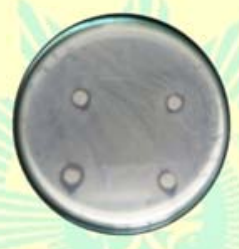

(b)

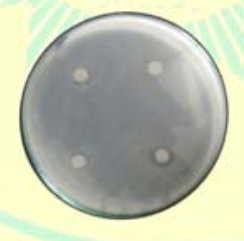

(e)

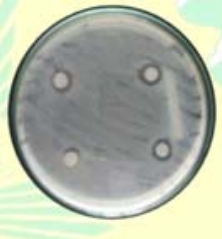

(c)

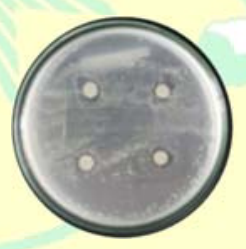

(f)

Gambar 2 Uji aktivitas antibakteri pada media NA dengan masa inkubasi 24 jam

a. Penghambatan isolat RTP-1 terhadap S. Aureus

b. Penghambatan isolat RTP-2 terhadap S. aureus

c. Penghambatan isolat RTP-3 terhadap S. Aureus

d. Penghambatan isolat RTP-1 terhadap E. coli

e. Penghambatan isolat RTP-2 terhadap E. coli

f. Penghambatan isolat RTP-3 terhadap E. coli

Hasil uji aktivitas antibakteri isolat Actinomycetes endofit dalam menghambat bakteri Gram positif $S$. aureus lebih kecil dibandingkan dengan bakteri Gram negatif $E$. coli, hal ini disebabkan adanya perbedaan struktur dinding sel kedua jenis bakteri tersebut. Bakteri Gram negatif memiliki lapisan peptidoglikan tipis sehingga lapisan dinding sel akan mudah dirusak oleh senyawa antibakteri yang dihasilkan. Menurut Radji 
(2011), dinding sel bakteri Gram positif terdiri atas beberapa lapisan peptidoglikan yang membentuk struktur yang tebal dan kaku serta mengandung substansi dinding sel yang disebut asam teikoat, sedangkan dinding sel bakteri Gram negatif terdiri atas satu atau lebih lapisan peptidoglikan yang tipis, sehingga dinding sel bakteri Gram negatif lebih rentan terhadap guncangan fisik seperti pemberian antibiotik atau bahan antibakteri lainnya.

Zona hambat yang terbentuk diasumsikan karena adanya senyawa antibakteri hasil metabolit sekunder yang disekresikan ke media yang dapat menghambat pertumbuhan dan membunuh bakteri patogen. Susilowati et al. (2007) menyatakan bahwa semakin banyak senyawa antibakteri yang disekresikan ke media semakin besar zona hambatnya.

Selain menghasilkan senyawa antibakteri, isolat Actinomycetes endofit diduga memiliki kandungan senyawa lain seperti antikanker, antiinflamasi, fitohormon dan antifungi. Das et al. (2003) mengemukakan bahwa Actinomycetes endofit yang diisolasi dari tanaman Trengguli (Cassia fistula L.) merupakan bakteri yang potensial menghasilkan berbagai macam metabolit sekunder seperti alkaloid, flavonoid, saponin dan lain-lain yang memiliki aktifitas biologis sebagai antikanker, dan antifungi. Kandungan senyawa metabolit sekunder yang dihasilkan kurang lebih sama dengan yang dihasilkan oleh $V$. zizanioides.

$V$. zizanioides menghasilkan senyawa metabolit sekunder seperti flavonoid, alkaloid, tanin dan saponin yang berfungsi menghambat atau membunuh pertumbuhan mikroorganisme patogen (Massardos et al.2005). Mekanisme kerja senyawa flavonoid yaitu dengan cara mendenaturasi protein sel mikroorganisme dan merusak membran sel tanpa dapat diperbaiki lagi. Senyawa alkaloid memiliki mekanisme penghambatan dengan cara mengganggu komponen penyusun peptodoglikan, sehingga lapisan dinding sel tidak terbentuk secara utuh dan menyebabkan kematian sel tersebut (Juliantina et al., 2008). Tanin memiliki peran sebagai antibakteri dengan cara mengikat protein sehingga pembentukkan dinding sel akan terhambat (Hateet et al., 2014). Saponin memiliki peran mengurangi permeabilitas membran sel yang mengakibatkan sel kekurangan nutrisi, sehingga pertumbuhan mikroorganisme patogen terhambat atau mati (Rahmawati, 2009)

\section{KESIMPULAN DAN SARAN}

Berdasarkan hasil penelitian dapat disimpulkan bahwa:

1. Diperoleh 3 isolat Actinomycetes endofit dalam jaringan tanaman akar wangi ( $V$. zizanioides) yaitu isolat RTP-1 dan RTP-2 dari jaringan daun dan RTP-3 dari jaringan akar.

2. Isolat RTP-1 memiliki aktivitas antibakteri terhadap S. aureus sebesar 1 $\mathrm{mm}$ (lemah), E. coli sebesar $20 \mathrm{~mm}$ (kuat), isolat RTP-2 terhadap S. aureus sebesar $9 \mathrm{~mm}$ (sedang), E. coli sebesar $4 \mathrm{~mm}$ (lemah), dan isolat RTP-3 terhadap S. aureus sebesar $7 \mathrm{~mm}$ (sedang), E. coli sebesar $9 \mathrm{~mm}$ (sedang).

\section{Saran}

Diperlukan penelitian lebih lanjut untuk karakterisasi kondisi pertumbuhan $(\mathrm{pH}$, suhu, media) optimum untuk produksi senyawa metabolit sekunder.

\section{DAFTAR PUSTAKA}

Akhila, dan Rani, M. 2002. Chemical Constituents and Essential Oil Biogenesis in Vetiveria zizaniodes. Dalam Massimo Maffei. Vetiveria : The Genus Vetiveria. Taylor and Francs Ind. New York. 
Amal, Abeer, Samia, Nadia, Ahmed, and Hennawi (2011). Selection of pigment (melanin) production in Streptomyces and their application in printing and dyeing of wool fabrics. Res.J.Chem.Sci.1(5):22-28.

Ambarwati, 2007. Efektifitas Zat Antibakteri Biji Mimba (Azadirachta indica) untuk Menghambat Pertumbuhan Salmonella typosa dan Staphylococcus aureus. Biodiversitas Vol 8 No.3.

Bacon and Hinton. Bacterial endophytes: the endophytic niche, its occupants, and its utility. Netherland: Springer; 2006.

Bailey, Bae, Strem, Roberts, Thomas, Crozier, Samuels, Choi, and Holmes. 2006. Fungal and plant gene expression during the colonization of cacao seedlings by endophytic isolates of four Trichodermaspecies. Planta 224:14491464.

Beck, Hansen, and Lauritsen.Novel pyrazine metabolites found in polymyxin biosynthesis byPaenibacillu spolymyxa. FEMS MicrobiolLett. 2003; (220):67-73.

Bentley, Lonnie, Whitten and Jeffrey L. 2002. Endophytic Actinomycetes Agriculture And Health. (7th edition). New York:McGrawHill.

Bhore and Sathisha. Screening of Endophytic Colonizing Bacteria For Cytokinin Like Compounds: Crude Cell Free Broth of Endophytic Colonizing Bacteria Is Unsuitable in Cucumber Cotyledon Bioassay. World J. Agric. Sci.2010;6(4):345-52.

Brooks, Geo, Butel, Janet, Morse, and Stephen. 2005. Mikrobiologi

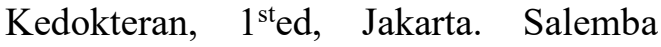
Medika, p 364-369.
Cao, Qiu, You, Tan, and Zhou.2004. Isolation and characterization of endophytic Streptomyces strain from surface sterilized tomato (Lycopersicones culentum) roots. Lett. Appl. Microbiol. 39:425-430.

Castillo, Strobel, and Ford. Munumbicins, wide-spectrum antibiotics produced by Streptomyces NRRL 30562, endophytic on Kennedia nigriscans. Microbiology. 2002; (148): 2675-85.

Chomchalow. 2000. Production of Medicinal and Aromatic Plants Vetivers Oil in Southeast Asia. AU J.T ; 4:84-94.

Clegg C and Murray P. 2002.Soil microbial ecology and plant root interaction. In: Gordon AJ (ed) 6th edn, IGER Innovations. pp. 36-39.

Coombs and Franco. 2003. Isolation and Identification of Actinobacteria From Surface Sterilized Wheat Roots. Appl Environ Microbial 69 (9): 5602-5608.

Das, Rajkumar, and Dwivedi. 2003. Aktivitas Antimikroba Metabolit Bioaktif Actinomycetes Endofitik Tanaman Trengguli (Cassia fistula L.). 3(2): 97102.

Guan, Sattler, Lin, Guo, and Grabley.pAminoacetophenonicacids produced by a mangrove endophyte: Streptomyces griseus subspecies. J Nat Prod. 2005; 68:1198-200.

Hateet, Muhsin, and Humadi. 2014. Antibacterial activity secondary metabolites from endophytic fungus Fusarium solani. Journal of basrah researches. 4 (1):94-101.

Herlina, Rante, Wahyono, Yosi, B. Murtidan Gemini Alam. 2010. Purifikasi dan Karakterisasi Senyawa Antibakteri dari Actinomycetes Asosiasi Spons Terhadap 
Bakteri Patogen Resisten. Majalah Farmasi Indonesia, 21 (3): 158-165.

Hermawan, A., 2007, Pengaruh Ekstrak Daun Sirih (Piper betle L.) terhadap Pertumbuhan Staphylococcus aureus dan Escherichia coli dengan Metode Difusi Disk, Artikel Ilmiah, Fakultas Kedokteran Hewan, Universitas Airlangga Surabaya.

Hidayaningtias. 2008. Perbandingan Efek Antibakteri Air Seduhan Daun Sirih (Piper betle L.) terhadap Streptococcus Mutans pada Waktu Kontak dan Konsentrasi yang Berbeda. Semarang: Universitas Dipenegoro.

Jawetz, Melnick, and Adelberg. 2005. Mikrobiologi Kedokteran, diterjemahkan oleh Mudihardi, Kuntaman, Wasito, Mertaniasih, Harsono, Alimsardjono, Edisi XXII, 205, 209-223, 317-326, 362363, Penerbit Salemba Medika, Jakarta.

Juliantina, Citra, Nirwani, Nurmasitoh, dan Bowo. 2008. Kandungan metabolit sekunder Sirih Merah (Piper crocatum) sebagai Agen Anti Bakteri Terhadap Gram Positif dan Gram Negatif. Jurnal Kedokteran dan Kesehatan Indonesia.

Khamma, Yokota, and Lumyong. 2009. Actinomycetes Isolated from Medicial Plant Rhizosphere Soils: Diversity and Screening of Antifungal Compounds, Indole-3-Acetic Acid and Siderophore Production. World J Microbial Biotechnol, 25: 649-655.

Lavania. 2003."Other Uses and Utilization of Vetiver: Vetiver Oil”, Central Institute of Medicinal and Aromatic Plants, Lucknow-336 015, India.

Lestari. 2006. Bakteri Endofit Penghasil Senyawa Bioaktif. Fakultas Pendidikan
Matematika Universitas Negeri Semarang.

Lo, Lai, Cheach, Wong, and Ho. 2002. Actinomycetes isolated from sample crokcer range sabah. Asean review of biodivercity ang enveromental conversation (ARBEC)

Massardos, Annie, Andre, Didiet, Andre, Jean. 2008. Flavonoids from Vetiveria zizanioides and Vetiveria nigritana (Poaceae), Biochemical Systematics and Ecology, 36, 68-70.

Miyadoh and Otoguro. 2004. Workshop on Isolation Methods and Classification Of Actinomycetes. Biotechnology Center LIPI.

Mulyati, Setiawan, dan Rusli. 2009. Rancang Bangun Sistem Manajemen Rantai Pasokan dan Risiko Minyak Akar Wangi Berbasis IKM di Indonesia. Bogor (ID): Institut Pertanian Bogor.

Oskay, Tamer, and Azeri. 2004. Antibacterial Activity of some Actinomycetes Isolated from Farming Soil of Turkey. African Journal of Biotechnology, 3(9) : 441446.

Radji. 2011. Buku Ajar Mikrobiologi, Panduan Mahasiswa Farmasi dan Kedokteran, 50. Jakarta, EGC.

Rahmawati, R. 2010. Uji Aktivitas Antibakteri Metanol Rhizoma Alang-alang(Imperata cylindrical L.) terhadap Pertumbuhan Escherichia coli dan Staphylococcus aureus. UniversitasTanjungpura, Pontianak

Ratha, 2012. Screening of Phytochemical and Antibacterial Activity of Hemidesmus indicus L. And Vetiveria zizanoides. Pelagia research library. European Jurnal of Experimental Biology, 2012, 2 (2): 363-368. 
Sembiring, Ward, Cand Goodfellow. 2000. Selective Isolation and Characterisation of Members of the Sreptomyces violaceus niger clade associated with the roots of Paraserian the sfalcataria. Anton Leuwan Int. 78(3-4): 353-366.

Snigda, Sharma, Mohapatra, and Chauhan. 2013.An Overview on Vetiveria zizanioides. Research Journal of Pharmaceutical, Biological and Chemical Sciences. Department of pharmacology. Sunder Deep Pharmacy. India. Volume 4-3. No 777

Strobel, Daisy, Castillo and Harper. Natural products from endophytic microorganisms. J Nat Prod.2004;(67): 257-68.

Suarsana, Utama, dan Suartini. 2001. Aktivitas In vitro Senyawa Antimikroba dari Streptococcus lactis. Jvet 2(1). Jurnal veteriner. Fakultas Kedokteran Hewan Universitas Udayana. Bali.

Suliantari. 2009. Aktivitas Antibakteri dan Mekanisme Penghambatan Ekstrak Sirih Hijau (Piper Betle Linn.) terhadap Bakteri Patogen Pangan. Disertasi. Institut Pertanian Bogor.

Sulistiyaningsih. 2010. Uji Kepekaan Beberapa Sediaan Antiseptik Terhadap Bakteri Staphylococcus aureus dan Staphylococcus aureus Resisten Metisilin (MRSA). Skripsi. Universitas Padjadjaran.
Susilowati, Hastuti, dan Yuniarti. 2007. Isolasi dan Karakterisasi Actinomycetes Penghasil Antibakteri Enteropatogen Escherichia coli K1.1, Pseudomonas pseudomallei 0205 dan Lestari Amonocytogenes 5407. Journal Agro Biogen 3(1): 15-23

Sutton, S. 2011. Determination of Inuculum for Microbiological Testing. Summer Vol. 15 Number 3.

Tanaka, Sukiman, Takebayashi, Saito, Suto, Prana and Tomita. isolation, screening and phylogenetic identification of endophytes from plants in Hokaido Japan and Java Indonesia. Microbes and Environment. 1999; 14(4):237-41.

Todar. 2002. Bacteriology. University of Wisconsin-Madison Department Of Bacteriology.

http://www.bact.wisc.edu/bact3330/lectu restaph.html [23-3-2017].

Truong. Tan Van and Pinners. 2008. Vetiver Systems Application, Technical Reference Manual. TheVetiver Network International. pp. 89.

Waluyo, Lud. 2009. Mikrobiologi Lingkungan. Malang: UMM Press.

Worang, R. L. 2003. Fungi Endofit sebagai Penghasil Antibiotika. Tesis S2 Fakultas Biologi Yogyakarta, UGM. 